\title{
FAKTOR-FAKTOR YANG BERHUBUNGAN DENGAN BERAT BADAN BAYI BARU LAHIR DI WILAYAH PRAKTIK MANDIRI BIDAN RIRIN SEVDA KORINI, AM.KEB KABUPATEN OGAN KOMERING ULU TAHUN 2020
}

\author{
FACTORS RELATED TO THE WEIGHT OF A NEW BABY BIRTH IN THE PRACTICES \\ AREA BIDAN RIRIN SEVDA KORINI, AM.KEB KABUPATEN OGAN KOMERING ULU, \\ 2020 \\ Heriani \\ Program Studi Kebidanan Sekolah Tinggi Ilmu Kesehatan Al-Ma’arif Baturaja Sumatera \\ Selatan \\ email: herianierawan@gmail.com
}

\begin{abstract}
ABSTRAK
Menurut WHO (World Health Organization), ialah sebesar 35 per 1.000. Angka kematian bayi merupakan tolak ukur yang sensitive dari semua upaya intervensi yang dilakukan oeleh pemerintah khususnya di bidang kesehatan. Penelitian ini menggunakan data sekunder dari responden dengan alat bantu cek-list sebagai pendoman untuk memperoleh data yang ada di bidan praktik mandiri, sampel 40. Analisa data menggunakan analisa univariat dan bivariat.Pada analisa bivariat didapatkan ada hubungan yang bermakna antara hubungan kenaikan berat badan ibu semasa kehamilan ( $p$ value 0,005$)$, usia ibu ( $p$ value 0,026$)$, paritas ( $p$ value 0,004$)$ dengan kejadian berat badab bayi baru lahir di PMB Ririn Sevda Korini, Am.Keb Kabupaten Ogan Komering Ulu tahun 2020. Ada hubungan yang bermakna antara kenaikan berat badan ibu semasa kehamilan, usia ibu, dan paritas dengan kejadian berat badan bayi baru lahir di PMB Ririn Sevda Korini, Am.Keb Kabupaten Ogan Komering Ulu tahun 2020 .
\end{abstract}

Kata Kunci : berat badan bayi baru lahir, kenaikan berat badan ibu semasa kehamilan, usia ibu, paritas

\begin{abstract}
According to WHO (World Health Organization), this is 35 per 1,000. The infant mortality rate is a sensitive measure of all intervention efforts undertaken by the government, especially in the health sector. This study uses secondary data from respondents with a check-list tool as a guide to obtain existing data on independent midwives, sample 40. Data analysis uses univariate and bivariate analysis. In the bivariate analysis, it was found that there was a significant relationship between maternal weight gain during pregnancy ( $p$ value 0.005), maternal age ( $p$ value 0.026), parity ( $p$ value 0.004) with the incidence of new birth weight in PMB Ririn Sevda. Korini, Am.Keb, Ogan Komering Ulu Regency in 2020. There is a significant relationship between maternal weight gain during pregnancy, maternal age, and parity with the incidence of new birth weight in PMB Ririn Sevda Korini, Am.Keb, Ogan Komering Ulu Regency in 2020.
\end{abstract}

Keywords: newborn weight, maternal weight gain during pregnancy, maternal age, parity. 
CENDEKIA MEDIKA

p-ISSN: 2503-1392

e-ISSN: 2620-5424

\section{PENDAHULUAN}

Angka kematian bayi merupakan tolak ukur yang sensitive dari semua upaya intervensi yang dilakukan oeleh pemerintah khususnya di bidang kesehatan.. AKB menurut World Health Organization (WHO) ialah sebesar 35 per $1.000^{1}$.

Indonesia menempati urutan kedua sebagai Negara dengan angka kematian ibu dan bayi tertinggi di Asia tenggara. Setiap 1 jam, 2 ibu dan 8 bayi baru lahir meninggal di Indonesia. Angka tersebut membuat Indonesia masuk dalam 10 negara dengan jumlah kematian ibu dan bayi baru lahir tertinggi ${ }^{2}$.

Bayi baru lahir (BBL) Adalah bayi yang baru dengan usia kehamilan atau masa gestasinya dinyatakan cukup bulan (Aterm) yaitu 36-40 minggu ${ }^{3}$. Berat badan bayi baru lahir merupakan interaksi dari berbagai faktor yang mempengaruhi diantaranya usia ibu, jarak kehamilan, paritas, kadar hemoglobin kenaikan berat badan ibu saat hamil, LILA, periksaan kehamilan, penyakit saat kehamilan, dan likungan sosial ekonomi. Untuk mencampai kebutuhan nutrisi yang diharapkan terpenuhi bagi ibu selama kehamilan dan janinnya, ibu hamil harus mencapai penambahan berat badan pada angka tertentu selama hamil ${ }^{4}$.

Berat Badan Lahir Rendah (BBLR) adalah bayi yang lahir dengan berat badan kurang dari 2.500 gram tanpa memandang masa kehamilan. Dahulu bayi baru lahir dengan berat badan kurang dari 2.500 gram atau sama dengan disebut premature. Sedangkan berat badan bayi normal adalah berat bayi yang lahir dengan berat badan 2.500 gram sampai 4000 gram.

Penelitihan ini bertujuan untuk mengetahui faktor-faktor yang berhubungan berat badan bayi baru lahir di Wilayah Kerja PMB Ririn Sevda Korini, AM.Keb Kabupaten Ogan Komring Ulu Tahun 2020.

\section{METODE}

Penelitihan ini menggunakan metode analitik dengan pendekatan dimana variable independen (Berat badan bayi lahir) dan variable dependen(kenaikan berat badan ibu kehamilan, usia ibu dan paritas) yang dikumpul dalam waktu bersamaan. Populasi dalam penelitian ini adalah ibu yang melahirkan dari bulan januari sampai November di wilyah kerja PMB Ririn Sevda Korini,AM,Keb Tanjung Agung Kecamatan Baturaja Barat Kabupaten Ogan Kombreng Ulu tahun 2020 yang berjumlah 40 orang.

Sampel dalam penelitian ini adalah total dari seluruh populasi yang bayi baru lahir normal berjumlah 40 orang. Teknik pengumpulan data menggunakan data sekunder. Instrumen penelitian ini menggunakan lembar Check List. Analisa yang dilakukan untuk melihat hubungan antara independen( berat badan bayi lahir) dan dependen (kenaikan berat badan ibu kehamilan, usia ibu dan paritas) menggunakan ujian static chi-square dan system komputerisasi dengan batas kemaknaan $\mathrm{a}=0,05$ dan deraja kepercayaan 95\%. Dikatakan adanya hubungan bermakna bila $\mathrm{p}$ value $>0,05$ maka kedua variabel tersebut dikatakan tidak ada hubungan bermakna.

\section{HASIL}

\section{Analisa Univariat}

Analisa ini dilakukan untuk mengetahui distribusi frekuensi dan persentasi dari Variabel Independen ( kenaikan berat badan ibu kehamilan, usia ibu dan paritas) dengan Variabel Dependen (berat badan 
CENDEKIA MEDIKA

p-ISSN: 2503-1392

e-ISSN: 2620-5424

bayi lahir) serta data disajikan dalam bentuk tabel teks.

Tabel 1 Distribusi Frekuensi Berat Badan Bayi Lahir

\begin{tabular}{l|l|c}
\hline Berat Badan Bayi Baru Lahir & Frekuensi & \% \\
\hline Normal & 20 & 50,0 \\
\hline Tidak Normal & 20 & 50,0 \\
\hline Total & 40 & 100 \\
\hline
\end{tabular}

Dari tabel 1 dapat diketahui bahwa dari 40 responden yang normal mengalami kejadian berat badan bayi lahir sebanyak 20 responden $(50,0 \%)$ dan responden yang tidak normal jarak berat badan bayi lahir sebanyak 20 responden $(50,0 \%)$.

Tabel 2 Distribusi Frekuensi Kejadian Kenaikan Berat Badan Ibu Semasa Kehamilan

\begin{tabular}{l|c|c}
\hline \multicolumn{1}{c|}{ Kenaikan Berat Badan Ibu selama kehamilan } & Frekuensi & \% \\
\hline Naik & 29 & 72,0 \\
\hline Tidak Naik & 11 & 27,0 \\
\hline Total & 40 & 100 \\
\hline
\end{tabular}

Dari tabel 2 dapat diketahui bahwa dari 40 responden yang naik mengalami kejadian kenaikan berat badan ibu selama kehamilan sebanyak 29 responden $(72,0 \%)$

\section{Tabel 3 Distribusi Frekuensi Kejadian Usia Ibu}

\begin{tabular}{l|c|c}
\hline \multicolumn{1}{c|}{ Usia Ibu } & Frekuensi & $\mathbf{\%}$ \\
\hline Tidak Beresiko & 18 & 45,0 \\
\hline Beresiko & 22 & 55,0 \\
\hline Total & 40 & 100 \\
\hline
\end{tabular}

Dari tabel 3 dapat diketahui bahwa dari 40 responden yang tidak beresiko mengalami kejadian usia ibu sebanyak 18 responden $(45,0 \%)$ dan responden yang beresiko

\section{Tabel 4 Distribusi Frekuensi Kejadian Paritas}

\begin{tabular}{l|c|c}
\hline \multicolumn{1}{c|}{ Paritas } & Frekuensi & $\mathbf{\%}$ \\
\hline Tidak Beresiko & 18 & 45,0 \\
\hline Beresiko & 22 & 55,0 \\
\hline Total & 40 & 100 \\
\hline
\end{tabular}

Dari tabel 4 dapat diketahui bahwa dari 40 responden yang tidak beresiko mengalami kejadian paritas sebanyak 18 responden $(45,0 \%)$ dan responden yang beresiko dan responden yang tidak naik jarak kenaikan berat badan ibuselama kehamilan sebanyak 11 responden $(27,0 \%)$.

jarak usia ibu sebanyak 22 responden $(55,0 \%)$.

jarak paritas sebanyak 22 responden $(55,0 \%)$. 
CENDEKIA MEDIKA

p-ISSN: 2503-1392

e-ISSN: 2620-5424

Analisis Bivariat

Analisis ini dilakukan untuk mengetahui hubungan antara Variabel Independen (kenaikan berat badan ibu kehamilan, usia ibu, paritas) dengan Variabel Dependen (berat badan bayi lahir) dengan batas kemaknaan $p$ value $\leq 0,05$ artinya ada hubungan bermakna (signifikan) dan bila $p$ value > 0,05 maka hubungan tidak bermakna uji statistic digunakan adalah ujian chi-squre.

Hubungan Kenaikan Berat Badan Ibu Semasa Kehamilan Dengan Kejadian Berat Badan Bayi Lahir

Tabel 5. Hubungan Kenaikan Berat Badan Ibu Kehamilan Dengan Kejadian Berat Badan Bayi Lahir

\begin{tabular}{|c|c|c|c|c|c|c|c|c|}
\hline \multirow{3}{*}{ No } & \multirow{3}{*}{$\begin{array}{c}\text { Berat Badan } \\
\text { Bayi Baru Lahir }\end{array}$} & \multicolumn{4}{|c|}{ Kenaikan Berat Badan Ibu semasa kehamilan } & \multirow{3}{*}{$\Sigma$} & \multirow{3}{*}{$\%$} & \multirow{3}{*}{$\begin{array}{c}P \\
\text { Value }\end{array}$} \\
\hline & & \multicolumn{2}{|c|}{ Normal } & \multicolumn{2}{|c|}{ Tidak Normal } & & & \\
\hline & & $\mathbf{F}$ & $\%$ & $\mathbf{F}$ & $\%$ & & & \\
\hline 1. & Normal & 19 & 47.5 & 1 & 2.5 & 20 & 50.0 & \\
\hline 2. & Tidak Normal & 10 & 25.0 & 10 & 25.0 & 20 & 50.0 & 5.005. \\
\hline & Jumlah & 29 & 72.5 & 11 & 27,5 & 40 & 100.0 & \\
\hline
\end{tabular}

Dari tabel 5. disimpulkan bahwa ibu yang bayinya mengalami berat badan bayi lahir yang kenaikan berat badan ibu kehamilannya naik sebanyak 19 responden $(47,5 \%)$ dan bayinya mengalami berat badan bayi lahir yang kenaikannya tidak naik sebanyak 10 responden $(25,0 \%)$. Berdasarkan analisa bivariat hasil uji statistic chi-square diperoleh $p$ value 0.005 hal ini menunjukan bahwa ada hubungan

Hubungan Usia Ibu Dengan Kejadian Berat Badan Bayi Lahir

Tabel 6 Hubungan Usia Ibu Dengan Kejadian Berat Badan Bayi Lahir

\begin{tabular}{|c|c|c|c|c|c|c|c|c|}
\hline \multirow{3}{*}{ No } & \multirow{3}{*}{$\begin{array}{c}\text { Berat Badan } \\
\text { Bayi Baru } \\
\text { Lahir }\end{array}$} & \multicolumn{4}{|c|}{ Usia Ibu } & \multirow{3}{*}{$\Sigma$} & \multirow{3}{*}{$\%$} & \multirow{3}{*}{$P$ Value } \\
\hline & & \multicolumn{2}{|c|}{ Tidak beresiko } & \multicolumn{2}{|c|}{ beresiko } & & & \\
\hline & & $\mathbf{F}$ & $\%$ & $\mathbf{F}$ & $\%$ & & & \\
\hline 1. & Normal & 13 & 32,5 & 7 & 17,5 & 20 & 50.0 & \multirow{2}{*}{0.026} \\
\hline 2. & Tidak Normal & 5 & 12,5 & 15 & 37,5 & 20 & 50.0 & \\
\hline & Jumlah & 18 & 47,7 & 22 & 55,0 & 40 & 100.0 & \\
\hline
\end{tabular}

Dari tabel 6 disimpulkan bahwa ibu yang bayinya mengalami berat badan bayi lahir yang usia ibu tidak beresiko sebanyak 13 responden $(32,5 \%)$ dan bayinya mengalami usia yang beresiko sebanyak 5 responden $(12,5 \%)$. Berdasarkan analisa bivariat hasil uji statistic chi-square diperoleh $p$ value 0.026 hal ini yang bermakna antara kenaikan berat badan ibu kehamilan dengan berat badan bayi lahir sehingga hipotesis yang mengatakan bahwa adanya hubungan yang bermakan antara berat badan lahir dengan kenaikan berat badan ibu kehamilan 
p-ISSN: 2503-1392

e-ISSN: 2620-5424

Hubungan Paritas Dengan Kejadian Berat Badan Bayi Lahir

Tabel 7 Hubungan paritas Dengan Kejadian Berat Badan Bayi Lahir

\begin{tabular}{|c|c|c|c|c|c|c|c|c|}
\hline \multirow{3}{*}{ No } & \multirow{3}{*}{ Paritas } & \multicolumn{4}{|c|}{ Berat Badan Bayi Lahir } & \multirow{3}{*}{$\Sigma$} & \multirow{3}{*}{$\%$} & \multirow{3}{*}{$P$ Value } \\
\hline & & \multicolumn{2}{|c|}{ Tidak beresiko } & \multicolumn{2}{|c|}{ beresiko } & & & \\
\hline & & $\mathbf{F}$ & $\%$ & $\mathbf{F}$ & $\%$ & & & \\
\hline 1. & Normal & 14 & 35.0 & 6 & 15.0 & 20 & 50.0 & \multirow{2}{*}{0.004} \\
\hline \multirow[t]{2}{*}{2.} & Tidak Normal & 4 & 10.0 & 16 & 40.0 & 20 & 50.0 & \\
\hline & Jumlah & 18 & 45.0 & 22 & 55.0 & 40 & 100.0 & \\
\hline
\end{tabular}

Dari tabel 7 disimpulkan bahwa ibu yang bayinya mengalamin berat badan bayi lahir yang paritas tidak beresiko sebanyak 14 responden $(35,0 \%)$ dan bayinya mengalami paritas yang beresiko sebanyak 4 responden $(10,0 \%)$. Berdasarkan analisa bivariat hasil uji statistic chi-square diperoleh $p$ value 0.004 hal ini menunjukan bahwa ada hubungan yang bermakna antara paritas dengan berat badan bayi lahir sehingga hipotesis yang mengatakan bahwa adanya hubungan yang bermakan antara berat badan lahir dengan paritas.

\section{PEMBAHASAN}

Hubungan Kenaikan Berat Badan Ibu Kehamilan

Dari hasil penelitian didapatkan ibu yang bayinya mengalami berat badan bayi lahir yang kenaikan berat badan ibu kehamilannya naik sebanyak 19 responden $(47,5 \%)$ dan bayinya mengalami berat badan bayi lahir yang kenaikannya tidak naik sebanyak 10 responden $(25,0 \%)$. Berdasarkan analisa bivariat hasil uji statistic chi-square diperoleh $p$ value 0.005 hal ini menunjukan bahwa ada hubungan yang bermakna antara kenaikan berat badan ibu kehamilan dengan berat badan bayi lahir sehingga hipotesis yang mengatakan bahwa adanya hubungan yang bermakan antara berat badan lahir dengan kenaikan berat badan ibu kehamilan

Rerata kenaikan berat badan ibu saat hamil pada penelitian ini didapatkan sebanyak
9,4 kg. Data distribusi frekuensi kenaikan berat badan ibu saat hamil. Hasil uji Fisher's Exact pada didapatkan nilai $\mathrm{p}$ sebesar 0.06 yang berarti tidak terdapat hubungan antara kenaikan berat badan ibu saat hamil dengan berat badan bayi lahir walaupun secara deskriptif berdasarkan umur, paritas, dan jarak kelahiran terdapat hubungan antara kenaikan berat badan ibu saat hamil dengan berat bayi lahir. Hasil ini sesuai dengan penelitian yang dilakukan oleh Sri Wahyuni dan Yeti Kadariyah (2015) $)^{5}$.

Kenaikan berat badan ibu hamil pada penelitian ini sesuai dengan rekomendasi Depkes RI (2013) bahwa kenaikan berat badan yang normal untuk ibu hamil di Indonesia sebesar 9- $12 \mathrm{~kg}$. Sebagian besar kenaikan berat badan ibu saat hamil merupakan komponen dari uterus dan isinya, lalu disusul dengan komponen payudara, volume darah, dan cairan ekstraseluler ${ }^{6}$.

\section{Usia Ibu}

Dari hasil penelitian didapatkan ibu yang bayinya mengalami berat badan bayi lahir yang usia ibu tidak beresiko sebanyak 13 responden $(32,5 \%)$ dan bayinya mengalami usia yang beresiko sebanyak 5 responden $(12,5 \%)$. Berdasarkan analisa bivariat hasil uji statistic chi-square diperoleh $p$ value 0.026 hal ini menunjukan bahwa ada hubungan yang bermakna antara usia ibu dengan berat badan bayi lahir sehingga hipotesis yang mengatakan bahwa adanya hubungan yang 
CENDEKIA MEDIKA

p-ISSN: 2503-1392

e-ISSN: 2620-5424

bermakan antara berat badan lahir dengan usia ibu.

Ibu hamil dengan kelompok usia lebih muda (21-25 tahun) memiliki bayi BBLR hanya $8,3 \%$, sedangkan pada usia ibu hamil lebih tua yaitu 31-35 tahun sebanyak $12,5 \%$. Hasil pengujian statikstik dengan chisquare didapatkan nilai $p 0,05$ yang berarti yang berhubungan yang bermakna antara usia ibu dengan berat badan bayi baru lahir Ibu hamil dengan kelompok usia lebih muda (21-25 tahun) memiliki bayi BBLR hanya $8,3 \%$, sedangkan pada usia ibu Pada teorinya, usia ibu yang sangat muda, masih dalam usia pertumbuhan memiliki risiko yang lebih tinggi melahirkan bayi dengan berat badan lebih rendah karena terdapat kompetisi antara bayi dan ibunya sebab ibu masih berada pada usia pertumbuhan ${ }^{6}$.

Hubungan paritas dengan kejadian berat badan bayi lahir

Dari hasil penelitian didapatkan ibu yang bayinya mengalamin berat badan bayi lahir yang paritas tidak beresiko sebanyak 14 responden $(35,0 \%)$ da`n bayinya mengalami paritas yang beresiko sebanyak 4 responden $(10,0 \%)$. Berdasarkan analisa bivariat hasil uji statistic chi-square diperoleh $p$ value 0.004 hal ini menunjukan bahwa ada hubungan yang bermakna antara paritas dengan berat badan bayi lahir sehingga hipotesis yang mengatakan bahwa adanya hubungan yang bermakan antara berat badan lahir dengan paritas.

Hasil penelitian ini sejalan dengan hasil penelitihan yang dilakukan oleh tabrizi(2017) terdapat $p$ value $=0,137$ yang berarti ada hubungan antara paritas dengan kejadian BBL

Ibu hamil dengan kelompok usia lebih muda (21-25 tahun) memiliki bayi BBLR hanya $8,3 \%$, sedangkan pada usia ibu Pada teorinya, usia ibu yang sangat muda, masih dalam usia pertumbuhan memiliki risiko yang lebih tinggi melahirkan bayi dengan berat badan lebih rendah karena terdapat kompetisi antara bayi dan ibunya sebab ibu masih berada pada usia pertumbuhan ${ }^{6}$.

Dalam penelitihan ini didapatkan bahwa ibu hamil dengan usia berisiko lebih besar BBRL dikerenakan status gizi yang kurang baik, premature, pre eklamsia, tekanan darah dan kekurangan tidur dari pada ibu hasil usia tidak beresiko.

\section{KESIMPULAN}

Berdasarkan penelitian di Ririn Sevda Korini, AM,Keb Tanjung Agung Kecamatan Baturaja Barat Kabupaten Ogan Kombreng Ulu tahun 2020 dapat ditarik kesimpulan sebagai berikut

1. dari 40 responden yang normal mengalami kejadian berat badan bayi lahir sebanyak 20 responden $(50,0 \%)$ dan responden yang tidak normal jarak berat badan bayi lahir sebanyak 20 responden $(50,0 \%)$.

2. dari 40 responden yang naik mengalami kejadian kenaikan berat badan ibu selama kehamilan sebanyak 29 responden $(72,0 \%)$ dan responden yang tidak naik jarak kenaikan berat badan ibuselama kehamilan sebanyak 11 responden $(27,0 \%)$.

3. dari 40 responden yang tidak beresiko mengalami kejadian usia ibu sebanyak 18 responden $(45,0 \%)$ dan responden yang beresiko jarak usia ibu sebanyak 22 responden $(55,0 \%)$.

4. dari 40 responden yang tidak beresiko mengalami kejadian paritas sebanyak 18 responden $(45,0 \%)$ dan responden yang beresiko jarak paritas sebanyak 22 responden $(55,0 \%)$.

5. Ada hubungan yang bermakna antara kenaikan berat badan ibu kehamilan dengan kejadian berat badan bayi lahir dengan hasil analisa Bivariat hasil uji 
CENDEKIA MEDIKA

p-ISSN: 2503-1392

e-ISSN: 2620-5424

statistic Chi-square di peroleh $p$ value yaitu 0.005

6. Ada hubungan yang bermakna antara usia ibu dengan kejadian berat badan bayi lahir dengan hasil analisa Bivariat hasil uji statistic Chi-square di peroleh $p$ value yaitu 0.026

7. Ada hubungan yang bermakna antara paritas dengan kejadian berat badan bayi lahir dengan hasil analisa Bivariat hasil uji statistic Chi-square di peroleh $p$ value yaitu 0.004

\section{SARAN}

Hasil penelitian ini dapat digunakan sebagian masukan dalam program kesehatan reproduksi untuk menurunkan angka kejadian berat badan bayi lahir (BBL) dan perbaikan mutu pelayanan kesehatan.

\section{DAFTAR PUSTAKA}

1. WHO. World Health Statistics 2015: World Health Organization; 2015

2. Kementrian Kesehatan RI. 2018. Profil Kesehatan Indonesia 2017. Jakarta: Kemenkes RI. Diakses pada tanggal 31 Januari 2019 dari http://www.depkes.go.id/resources/do wnload/pusdatin/profil-kesehatanindonesia/Profil-Kesehatan-Indonesiatahun-2017.pdf

3. Mitayani. (2011).Asuhan Keperawatan maternitas. Jakarta: Salemba Medika

4. Asmawati N, Fitriana, Nopi Anggista Putri. 2016. Faktor-Faktor Yang Berhubungan Dengan Berat Badan Bayi Baru Lahir Di Wilayah Kerja Puskesmas Seputih Raman Lampung Tengah Tahun 2016. Journal Gizi Aisyah. Stikes Aisyah Pringsewu.http://journal.aisyahunivers ity.ac.id/index.php/JGA/article/view/ NanikAsmawati/NanikAsmawati

5. Wahyuni S Dan Yeti Kadariyah. 2010. Hubungan Peningkatan Beratbadan Ibu Hamildengan Berat Badan Bayi Baru Lahirdi Bps Bekti Sayekti S.Sit Tarubasankaranganom Klaten. Jurnal Involusi Kebidanan, Vol. 1, No. 1, Januari 2011, 20-31

6. Prawirohardjo. 2011. Ilmu Kebidanan. Jakarta: PT. Bina Pustaka Sarwono Prawirohardjo. 